\title{
İlk ve orta öğretimde uygulanan şiddet olaylarına öğretmen adayı öğrencilerin anlatılarından bakmak
}

\author{
Mustafa GÜNDÜZ*
}

\section{Özet}

Farklı amaçlarla bir başkasına istenmeyerek etkide bulunma eylemi olarak tanımlanan şiddetin değişik sebep ve uygulama biçimleri vardır. Şiddet hayatın hemen her döneminde ve çok farklı yerlerde görülebilmektedir. Bu dönem ve mekânlardan biri ve belki de en önemlisi okuldur. Eğitimde şiddet sürekli gündemde olan bir problemdir. Kişiler üzerinde derin etkiler bırakmasına ve asla istenmemesine karşın, hâlâ varlığını devam ettirmekte ve giderek de artmaktadır. Eğitimdeki şiddete yönelik geniş, sağlıklı ve yeterli araştırmalar bulunmamaktadır. Bu araştırmada, öğretmen adayı üniversite 300 son sınıf öğrencisi bu güne kadar eğitim ortamlarında tecrübe ettikleri ya da şahit oldukları bir şiddet olayını yazılı olarak anlatmıştır. Anlatılanlar sayısal olarak ve nitelik açısından analiz edilmiştir. Öğrencilerin karşılaştıkları şiddet olayının özneleri, gerekçeleri, araçları, zaman ve mekânlarına ilişkin sınıflamalar yapılmıştır. Ayrıca şiddetin tipolojileri, uygulama biçimleri ve şiddete verilen tepkiler analiz edilmiştir. Araştırmada ortaya çıkan temel sonuçlara göre, Türk eğitim sisteminin son seviyesine gelip de şiddet görmeyen öğrenci yok gibidir. Şiddet sebeplerinde ve uygulama biçimlerinde farklılıklar vardır. Şiddet öğrencilerin benlik, kişilik, iletişim becerisi ve öğrenme yeteneklerini derin biçimde etkilemektedir.

Anahtar kelimeler: Okulda şiddet, okulda şiddet tipolojileri, şiddete tepkiler, şiddetin etkileri

\section{Understanding teacher candidates' opinions on violence in primary and secondary schools' explores the narratives}

\begin{abstract}
Describing violence as the act of inflicting an influence on someone regardless of his/her desire and consent for various purposes, has many kind of diverse reasons. It may be observed
\end{abstract}

* Doç.Dr., Yıldız Teknik Üniversitesi, Eğitim Fakültesi, Eğitim Bilimleri Bölümü, mstgndz@gmail.com 
in nearly every phase of human life and in many different settings. Violence in education is a problem that remains invariably on the agenda. Although it leaves profound impact on people and is never welcome, it still continues its existence and increases day by day. There are no enough comprehensive and quality studies on violence in education. In this study, a number of 300 senior student teachers reported, in written form, incidents of violence which they had experienced or witnessed within educational settings thus far. The narrations were analyzed quantitatively and qualitatively. Classifications regarding the subjects, reasons, means, times and settings of the acts of violence the students had encountered were made. Moreover, some analyses were carried out on the typologies, perpetration kinds of and reactions to violence. According to the basic result of research, there is no student who reaches the last level of the Turkish educational system without being exposed to violence. Violence deeply affects students' personality and communication skills and learning and teaching abilities.

Keywords: School-violence, reactions to violence, means of violence, effects of violence

\section{Giriş}

Şiddet, bir arada yaşamaya mecbur olan insanlar arasındaki rekabet, anlaşmazlık, hükümranlık ve iktidar kavgası gibi içgüdüsel bir dışavurum olarak insanlık tarihiyle yaşıttır. Lorenz, Freud ve Ardrey’e göre saldırganlık ve şiddet insan tabiatının bir parçasıdır (Akyol, 1991, s. 18). Tam anlamiyla çok boyutlu bir olgu (Debarbieux, 2009, s. 66; Furlong ve Morrison, 2000, s. 71) olan şiddetin ortak bir tanımı yapılmış değildir. Yves’e (1986) göre şiddet, gönüllülük esasına dayanmayan, bir şeyi bir başka duruma doğru değiştirmek ya da değişme yolundaki hareketini engellemek için uygulanan fiziksel ya da bir başka şekilde güç, baskı ya da zor kullanımıdır. Pek çok türü ve tanımı olmakla birlikte şiddet, bireysel özgürlügü zor yoluyla kısıtlama bireyin arzulamadığı bir durum için zor kullanma şeklinde tarif edilebilir (Bakır, 2008, s. 101; Hobart, 1996, s. 52). Dolayısıyla insanın tabiatında var olan ve istenmeyen davranışların ortaya çıkmaması ya da azaltılması için pek çok dini, sosyal, kültürel ve hukuki öğreti, önlem ve yaptırım düzenlenmiştir.

Eğitim ortamlarında her zaman planlanan ve öngörülenlerin dışında pek çok durum, olay, davranış vb. ortaya çıkar. Çünkü toplumsal değişme aynı zamanda eğitimi de her yönüyle etkiler. Hatta eğitimin zayıf kalması durumunda sosyal çevre öğrenciyi daha güçlü biçimde etkiler ve okuldan uzaklaştırır. Sosyal, kültürel, siyasi vb. değişimlere paralel eğitim ortam ve programları da değişmezse sürekli çelişkiler ortaya çıkar. Böylesi hallerde eğitimciler inisiyatif alır ve çoğu kez bireysel tercihler ve uygulamalar baskın hale gelir. Bu da eğitimin normatif yapısına ters bir süreç başlatır.

Okulda şiddet sorunu aslında gündelik, yinelenen, çok biçimli bir baskı sorunudur (Gerler, 2004). Eğitimin ve okulun bir şiddet ortamı olarak tasvir edilmesi ve araştırmaya konu edinilmesi aslında ironik ve bir o kadar da trajik bir durumdur. Ne var ki, bir arada yaşamanın zaruri 
olduğu hemen her mekânda sorun çıkması doğalsa, aynı mekânlarda farklı biçimlerde şiddetin de görülmesi sıradan görülebilir. Dolayısıyla eğitim ortamlarında tarihin en eski çağlarından bu güne kadar "eğitim adına" şiddetin yaşandığı bir gerçektir. Okulda şiddetin tarihi, "tarihin unutulmuşları" olan kurbanların yavaş yavaş keşfedilmesinin tarihidir (Garnot, 2000; akt. Debarbieux, 1996, s. 136).

Son zamanlarda diğer ülkelerde olduğu gibi (Gottfredson, 1985; Debarbieux, 2009), Türkiyede de okulda şiddet olayları artış göstermektedir (Gözütok, 1993; Hatipoğlu, 1999). Ancak eğitim ortamlarındaki şiddet üzerine gelişkin, temsil kabiliyeti yüksek araştırmaların, istatistiklerin varlığından söz edilemez (Gawrych, 1986). Bu konuda resmi otoritelerin geniş çaplı ve güvenilir istatistikleri de bulunmamaktadır (Debarbieux, 2009, s. 80). Ancak konunun öneminden hareketle yapılan bir hazırlıkta (Eğitim Ortamlarında Şiddetin Önlenmesi ve Azaltılması Stratejik ve Eylem Planı, 2006), şiddet olaylarına karşı alınacak önlemler ve eylem planı hazırlanmıştır.

Eğitim ortamlarında öğretme, davranış değiştirme ve düzeltme adına çok farklı türlerde şiddet tipolojileri ve davranışları görülmektedir (Ünsal, 1996, s. 29-36). Bunların başında fiziksel cezalar gelmektedir. Bunun yanında sözlü ve psikolojik, simgesel/sembolik, kurumsal, ekonomik ve cinsel şiddet gibi türler de eğitim ortamında görülebilmektedir.

Okulda görülen şiddetin nedenlerini araştırmak önemlidir. Toplumsal ve davranışsal olay ve olguların birden çok fazla nedeni olduğundan, tek bir hedef belirlemek doğru olamaz. Bunun yanında şiddetin kişilere göre de değişen nedenleri vardır. Bu araştırmada öğrenciler niçin şiddete uğradıklarını açıkça belirtmiş̧ler ve çok farklı durumlar zikretmişlerdir. Şiddetin meydana gelmesinde diğer tarafın (şiddet uygulayanın) gerekçeleri de oldukça önemlidir. Ancak bu araştırmada şiddet uygulayanlardan veri toplanmamıştır.

Teorik olarak eğitim ortamlarında şiddetin temel nedeni öğretme ve davranış değiştirmeyle ilgilidir. Okulda şiddeti uygulayanların birçoğu, "öğrencinin ya da diğerlerinin iyiliği için yaptıklarını" söyleyeceklerdir. Bunun geçerliliği tartışmalı olduğu gibi, çoğunlukla "keyfi" (Arendt, 2003, s. 8) olduğu görülmektedir. Şiddet kime göre gereklidir? Eğitimcinin zorla öğretmeye ya da davranış değiştirmeye hakkı var mıdır ve kendisinin bu konuda ne derece ehliyeti vardır? Bütün bunlar alanın en tartışmalı sorularıdır. Şiddet her durumda ortalama insanların ve toplumun kaçınmak istediği bir davranıştır. Şu halde, özellikle eğitim ortamlarının şiddetten arındırılmasına öncelikle sorunun tespiti ve detaylı tasviri ile başlanılabilir. Ardından ise kaldırılmasına yönelik çareler aranır.

Bu çalışmada, okuldaki şiddet eylemlerinin özne ve nesneleri yanında, biçimleri, sebepleri ve öğrenciler üzerindeki geçici ya da kalıcı etkileri üzerine biçimsel nitelikleri ağır basan bir tasvir/ betimleme yapılmıştır. Bu betimlede şiddetin doğrudan tanıklarları üzerinden gerçekleştirilmiştir. Buradan hareketle araştırmanın temel amacı, mesleki hayatını büyük ihtimalle öğretmen ya da eğitimci olmak üzere tercih edip, eğitim fakültesinde okuyan öğrencilerin, kendi eğitim geçmişlerinde karşılaştıkları şiddet olaylarına yönelik anlatılarında ortaya çıkan temel/ortak noktaları, belirgin davranış kalıplarını meydana çıkarmaktır. 


\section{Yöntem}

\section{Araştırmanın modeli}

$\mathrm{Bu}$ araştırma nitel araştırma yöntemine dayanmaktadır. Verilerin elde edilmesinde nitel araştırmanın vak’a/olay anlatımı tekniğinden yararlanılmıştır (Bailey, 1987). Bu metot ve veri toplama tekniğiyle güvenli ve geçerli bilgilerin elde edildiğine kuvvetle inanılmaktadır. Zira veriler, bireysel tecrübelerin dökümü ve bir anlamda samimi itiraflar niteliğindedir ve gönüllülük esasına dayanarak elde edilmiştir.

\section{Araştırmanın örneklemi}

Araştırmanın verileri, 2009-2010 eğitim-öğretim yılında Fırat Üniversitesi Eğitim Fakültesi’nde eğitim gören 400 son sınıf öğrencisinden sağlanmıştır. Araştırmaya katılım yaklaşık \%75 düzeyinde olmuş ve 300 kişi anekdot yazmıştır. 300 kişilik katılımcı çok farklı bölgelerden gelmiş ve yine bu kişiler çok farklı okullardan mezun olmuşlardır. Fırat Üniversitesi öğrencilerinin dağılım profili Tablo 1'de görüldüğü üzere \%36’sı Elazı̆̆’dan, \%31'i Doğu ve Güneydoğu Anadolu bölgesinden, geri kalanlar da diğer bölgelerdendir. Bu durum, çalışmanın Doğu ve Güneydoğu Anadolu bölgesi ölçeğinde araştırıldığını ve temsil kabiliyetinin yüksek olduğunu ortaya koymaktadir.

Tablo 1

20 10-20 I I Eğitim-Öğretim Yılı Resmi Verilerine Göre Fırat Üniversitesi Öğrenci Profili

\begin{tabular}{|l|c|c|c|c|}
\hline Bölgeler & Erkek & Kadın & Toplam & $\%$ \\
\hline Elazı̆̆ & 6304 & 4304 & 10608 & $\% 36$ \\
\hline Doğu Anadolu & 3065 & 1540 & 4605 & $\% 16$ \\
\hline Güneydoğu A. & 2858 & 1681 & 4539 & $\% 15$ \\
\hline Akdeniz & 1874 & 1156 & 3030 & $\% 10$ \\
\hline Marmara & 1919 & 625 & 2544 & $\% 9$ \\
\hline İç Anadolu & 1251 & 504 & 1755 & $\% 6$ \\
\hline Karadeniz & 931 & 312 & 1243 & $\% 4$ \\
\hline Ege & 820 & 262 & 1082 & $\% 4$ \\
\hline
\end{tabular}

\section{Verilerin toplanması ve analizi}

Araştırma, Eğitim Sosyolojisi dersine katılan öğrencilerin eğitim hayatlarında yaşadıkları bir şiddet olayını tamamıyla gönüllü olarak anlatılarına dayanmaktadır. Anekdot yazanların \%98’i kendi başından geçen hadiseyi yazmıştır. Sadece dört kişi "ben eğitim hayatım boyunca 
hiç şiddete uğramadım” dese de ilerleyen satırlarda bir şekilde şiddet gördüğünü anlatmıştır. Ad, numara ve sınıf yazmanın da isteğe bağlı olduğu ancak, istatistik yapılacağ 1 için bu bilgileri vermenin araştırma için önem taşıdığı belirtilmiştir. En önemlisi de, bu verilerin kimseyle paylaşılmayacağı, sadece bilimsel çalışmada kullanılacağı, kodlar verilerek analizlerin yapılacağ 1 ve özgün alıntılardan yararlanılabileceği ifade edilmiştir. Bu isteğe hiçbir öğrenciden eleştiri ya da itiraz gelmemiş, hatta anekdot yazan bütün öğrenciler ad, numara ve sınıflarını yazdıkları gibi, birçoğu da "araştırmanızda ismimizi de kullanabilirsiniz" demiştir. Sınıfların toplam sayıları ve araştırma için anekdot yazanların sayıları Tablo 2'de gösterilmiştir.

Tablo 2

Araştırmaya Veri Sağlayan Bölümler, Sınıf Mevcudu ve Anekdot Yazanlar

\begin{tabular}{|c|c|c|c|c|c|}
\hline \multirow{2}{*}{ Kodlar } & \multirow{2}{*}{ Bölümler } & \multirow{2}{*}{$\begin{array}{c}\text { Sinif } \\
\text { Mevcudu }\end{array}$} & \multicolumn{3}{|c|}{ Katılımcı Öğrenci Sayısı } \\
\hline & & & Kadın & Erkek & Toplam \\
\hline (FBI) & Fen Bilgisi Öğretmenliği I & 40 & 15 & 17 & 32 \\
\hline (FBII) & Fen Bilgisi Öğretmenliği II & 40 & 19 & 8 & 27 \\
\hline (SÖ) & Sınıf Öğretmenliği & 35 & 13 & 14 & 27 \\
\hline (TI) & Türkçe Öğretmenliği I & 35 & 13 & 16 & 29 \\
\hline (TII) & Türkçe Öğretmenliği II & 35 & 16 & 9 & 25 \\
\hline$(\mathrm{M})$ & Matematik Öğretmenliği & 30 & 12 & 18 & 20 \\
\hline (BI) & BÖTE I & 50 & 21 & 18 & 39 \\
\hline (BII) & BÖTE II & 50 & 11 & 32 & 43 \\
\hline (SI) & Sosyal Bilgiler Öğretmenliği I & 40 & 13 & 14 & 27 \\
\hline (SII) & Sosyal Bilgiler Öğretmenliği II & 40 & 13 & 19 & 32 \\
\hline 10 & Toplam & 395 & 146 & 154 & 300 \\
\hline
\end{tabular}

Öğrencilerin maruz kaldıkları ya da tanık oldukları şiddet olayları analiz edilirken şu metot izlenmiştir: Veriler öncelikle cinsiyete göre ayrılmış ve her kâğılda numara verilmiştir. Metin içinde, Tablo 2'de gösterilen sınıf kodunun önüne kâğıt numarası verilerek, alıntının kime ait olduğu belirtilmiştir (Örneğin FBI 3, Fen Bilgisi Öğretmenliği I. Öğretim bölümü öğrencilerinden 3 numaralı kişi). 
$\mathrm{Bu}$ işlemden sonra şiddet görme biçimleri şu kodlar kullanılarak tablolaştırılmıştır. Bu bilgilerden sonra şiddet uygulama biçimi, şiddetin sebebi, şiddet araçları, öğrencinin şiddete gösterdiği tepki ve şiddetin üzerinde bıraktığı etki, şiddet olayında aile ve sosyal çevrenin rolü, şiddet uygulayanlar hakkında düşünülenler ve özgün alıntı başlıkları kullanılarak istatistiksel veriler oluşturulmuştur. Verilerin dağılımları, benzerlikleri ve zıtlıkları tespit edilerek yorumlar yapılmıştır.

Veriler incelendiğinde katılımcıların çoğu en az bir olayı, bazıları iki, üç hatta dört olayı anlatmışlardır. Çoğunluk bir sayfa ile yetinirken, bazı öğrenciler üç, bazıları da dört sayfa kadar şiddet hikâyesi yazmıştır. Yine bazı öğrenciler, başlarından geçen şiddet olayını anlatırken kaba hatlarıyla bir metin yazarken, büyük çoğunluk yaşadıklarını detaylıca hikâye etmiştir. $\mathrm{Bu}$ araştırmada anlatılan şiddet olayları ortalama 1997-2010 yılları arasında gerçekleşmiştir. Dolayısıyla yakın tarihe ve bu güne ait anekdotlardır. Dolayısıyla şiddete maruz kalanlar ve şiddet gösterenlerin halen eğitim ortamında olduğu söylenebilir.

\section{Bulgular}

\section{Şiddet görülen dönemler ve mekânlar}

Araştırmadaki anlatılarda şiddet görülen dönem ve okul yıllarına ilişkin verilen bilgiler Tablo 3’te gösterilmiştir. Bazı öğrenciler anlatılarında yer ve zaman konusunda bir ayrıntı vermemiştir. Şiddet olayının köy ya da kasaba ilkokulunda geçtiğini söyleyen birkaç örnek vardır. Büyük çoğunluğun şehir okullarında gerçekleştiği ihtimali güçlüdür. Anlatılardan çıkarılan bilgilere göre, şiddet olaylarının en çoğu ilkokulda (105), 99’u ortaokulda, 38’i lisede, 3’ü de üniversitede geçmiştir.

Şiddet türleri, sebepleri ve uygulama biçimleri konusunda da dönemlere göre belirgin bir farklılaşma söz konusudur. İlk ve orta öğretimde fiziksel şiddet daha yoğun görülürken, lisede ağır yaralanmalı, kavgalı, çok taraflı şiddet hadiseleri ortaya çıkmıştır. Üniversitede ise ekonomik ve yetki kullanımı şiddeti görülmektedir.

Tablo 3

Şiddet Görülen Okul Türleri

\begin{tabular}{|l|c|c|c|c|}
\hline Cinsiyet & İlkokul & Ortaokul & Lise & Üniversite \\
\hline Kadın & 67 & 52 & 17 & 2 \\
\hline Erkek & 38 & 47 & 21 & 3 \\
\hline Toplam & 105 & 99 & 38 & 1 \\
\hline
\end{tabular}


Öğrenciler şiddet gördükleri mekâna ilişkin de pek çok ayrıntıya yer vermişlerdir. Doğal olarak şiddet görülen mekânların başında sınıf ve sınıfa yakın yerler gelmektedir. Koridor, öğretmenler odası (FBI, 24), müdür odası, müdür yardımcısı odası, okul bahçesi, oyun sahaları, kütüphane, laboratuvar ve tören alanı en çok şiddet görülen yerlerdir. Bunların dışında ev, sokak, okul yurtları (FBI, 10, 25) ve Kur’an Kursları (FBI, 25) da şiddet mekânları arasında yer almaktadır. 10 öğrenci Yatılı İlköğretim Bölge Okulu (YİBO)'nda gördüğü şiddeti anlatmıştır. Burada yemekhane, yatakhane, lavabo, banyo, okuma salonu gibi yerlerde şiddet görmüşlerdir. Yedinci sinıf bir öğrenci, müdürün odasına ilk defa dayak yemek için girdiğini anlatmıştır (TII, 21).

\section{Şiddet gösteren kişiler}

Anlatılara göre en çok şiddet öğretmenlerden görülmüştür. 65 kişi ders öğretmeninden şiddet gördüğünü anlatırken, 41 kişi okul müdüründen, 31 kişi müdür yardımcısından şiddet görmüştür. Buna göre aslında okul idarecileri öğretmenlerden daha çok şiddet uygulamıştır. Ancak ilköğretimde şiddet bütünüyle öğretmenler tarafından uygulanırken, ortaöğretimde daha çok okul idarecileri şiddet uygulamıştır.

Tablo 4

Şiddet Gösteren Kişiler

\begin{tabular}{|l|c|c|c|c|c|c|c|}
\hline Cinsiyet & $\begin{array}{c}\text { Kadın } \\
\text { Öğretmen }\end{array}$ & $\begin{array}{c}\text { Erkek } \\
\text { Öğretmen }\end{array}$ & Müdür & $\begin{array}{c}\text { Müdür } \\
\text { Yrd. }\end{array}$ & $\begin{array}{c}\text { Nöbetçi } \\
\text { Ögretmen }\end{array}$ & Arkadaş & Hizmetli \\
\hline Kadın & 11 & 22 & 17 & 13 & - & 3 & 2 \\
\hline Erkek & 9 & 23 & 24 & 18 & 3 & - & - \\
\hline Toplam & 20 & 45 & 41 & 31 & 3 & 3 & 2 \\
\hline
\end{tabular}

\section{Şiddet görülen dersler}

Öğrencilerden 101 tanesi hangi dersin öğretmeninden şiddet gördüğünü belirtmemiştir. Tablo 5'in verilerine göre, en fazla şiddet Türkçe (25) ve Matematik (24) öğretmeninden gelmiştir. Bunlardan sonra ise Fen Bilgisi (13) ve İngilizce (10) dersleri gelmektedir. Diğer derslerde görülen şiddet olayları ise 10’un altındadır. Bu dört derste çok fazla şiddet olayı görülmesinin sebepleri arasında, dersin haftalık saat miktarı, önemi ve zorluk düzeyinin geldiği düşünülebilir. Özellikle ilk ve orta öğretimde Türkçe, Matematik, Fen Bilgisi ve İngilizce dersinin saat sayısı, önemi ve zorluk derecesi neredeyse diğerlerinin tamamına bedeldir. Öğretmenler, öğrenciler ve aileler en çok bu dersleri önemserler. Dolayısıyla da bu derslerin öğretiminde ve başarısında büyük zorluklar vardır. Şiddetin sebepleri arasında, öğrenme ve öğretme durumları en başta gelmektedir. $\mathrm{Bu}$ da adı geçen derslerin zorluk nedenlerinden dolayı bir yoğunlaşmayı beraberinde getirmiştir. 
Tablo 5

Şiddet Görülen Dersler

\begin{tabular}{|c|c|c|c|c|c|c|c|c|c|c|c|}
\hline Dersler & $\begin{array}{l}\stackrel{\mathscr{W}}{y} \\
\vdots \\
\vdots\end{array}$ & 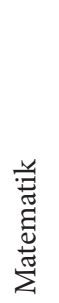 & $\begin{array}{l}\overrightarrow{\vec{n}} \\
\overrightarrow{b 0} \\
\overrightarrow{\vec{n}} \\
\overrightarrow{0} \\
\vec{w}\end{array}$ & 芯 & 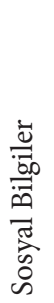 & 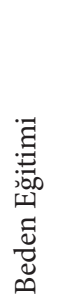 & 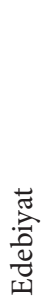 & 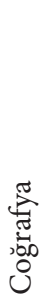 & 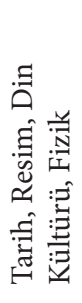 & 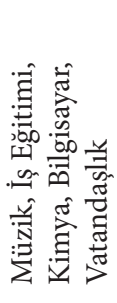 & 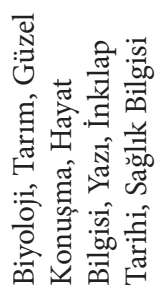 \\
\hline f & 25 & 24 & 13 & 10 & 8 & 6 & 5 & 4 & 3 & 2 & 1 \\
\hline
\end{tabular}

\section{Psikolojik rahatsızlıkları olan öğretmenler, idareciler ve şiddet}

Anlatılarda şiddet ve sebepleri konusunda ilginç ayrıntılardan biri olarak öğretmenlerin psikolojik durumları, davranışları hatta sağlıkları söz konusu edilmiştir. Pek çok öğrenci şiddet gördüğ̈̈ öğretmenini psikolojik olarak hasta, davranış bozukluğu gösteren biri olarak tanımlamıştır. Örneğin bir öğretmen, soru soruyor ve bir öğrenci cevap verince, "Sana mı sordum" diyerek cevap verene bir tokat atıyor (SÖ, 25). Bir diğerinde ise öğrenci "Tekrar eder misiniz" diyor ve öğretmen "Çık dışarı, çok ve gereksiz konuşuyorsun” (BI, 34) deyip öğrenciyi sınıfın dışına çıkarıyor.

Bazı öğretmenlerin ailevi, kişisel sorunlarını belirgin bir şekilde öğrencilere şiddet olarak yansıttıkları anlatılmıştır. Bir anlatıda "Öğretmenin aile geçimsizliği vardı, bazen başını masaya koyar orada bayılırdı" (FBI, 15) denilirken, bir diğerinde "Müdürün ailevi sorunları vardı" (BI, 24), "Müdür ailesi yüzünden gece okulda kalırdı” (FBI, 28), denilmektedir. Bir diğerinde “Öğretmenimiz dövdükten sonra kafasını masaya koyar, uzun süre kaldırmaz ve üzülürdü” (FBI, 5) denilerek ilginç bir durum anlatılır. Azımsanmayacak sayıda okula sarhoş gelen öğretmenden bahsedilmektedir (BI, 24). Böylelerinin sürekli psikolojik şiddet uyguladıkları dile getirilmiştir (SÖ, 4). Bir öğrenci, psikolojisinin bozulduğunu düşündüğü öğretmeninin evinde intihar ettiğini (TII, 11) yazmıştır.

\section{Okulda şiddetin görünen sebepleri}

Okul ve şiddet literatürüne bakıldığında, şiddete sebep olabilecek pek çok durum vardır. Bazı araştırmalarda (O’Donoghue, 1995; Debarbieux, 2009) ekonomik eşitsizliğin daha çok şiddet yarattığına ilişkin bulgulara yer verilmiştir.

Okulda cezalandırmanın çok farklı sebeplerinin olduğu görülür: Lavaboda öğrencilerin birbirlerine su atmaları, etrafın kirletilmesi, mendilin temiz olmaması, sınavda istenen düzeninin alınmaması, izinsiz okul dışına çıkma, sınıfta birine kâğıt atma, karnenin yıpratılması, tahtanın silinmemesi, ders araç-gerecinin getirilmemesi, arkadaşlardan birinin şikâyeti gibi durumla cezalandırmayla sonuçlanmıştır. 
Şiddet uygulama nedenleri içinde eğitim ve öğretim faaliyetlerindeki eksikler, başarısızlıklar ve ihmaller ön sırada yer almıştır. İlkokul birinci sınıfta düz çizgi çekemediği ve düzgün yazı yazamadığı için tokat yiyenler (FBI, 16) vardır. Noktalama işaretlerine uymadığı için cezalandırılan ve bunu unutamayanlar bulunmaktadır (SI, 14). Öğretmenin sorduğu soruya cevap veremediği için dayak yiyenler de bulunmaktadır. Hatta birçok öğrenci "soruyu bildiğim halde heyecanımdan ya da korktuğumdan doğru cevabı veremedim ve bu yüzden şiddet gördüm" demiştir. Ödev yapmamak, eksik ya da yanlış yapmak nerede ise sürekli şiddet konusu olmuştur. Hatta ödev verilirken bir öğrencinin gönülsüzce "Öf ya, yine mi ödev" demesi bile şiddet görmesine sebep olmuştur (M, 6). Sınav sırasında öğretmen "Kâğıdını getir" dediğinde öğrencinin getirmemesi (BI, 19) de onun cezalandırılmasına sebep olmuştur. Bunun yanında ödev yapmayıp, arkadaşının notlarını gösterdiğinden dolayı şiddet gören ve bunda öğretmenin haklı olduğunu söyleyenler (SI, 8) olmuştur. Özellikle bazı ezberlerin (İstiklal Marşı, Gençliğe Hitabe, Andımız vb.) yapılmaması (BII, 10; FBII, 6) çoğu kez dayakla cezalandırılmıştır.

Sınıf içerisindeki ilişkilerin istenmeyen yönlerinde de sıkça şiddet görülmüştür. Haşarılık nedeniyle "yazı tahtasını kırmak" (BI, 3), "sınıf lambalarını gevşetmek" (SII, 15) şiddete sebep olmuştur. Bir öğrencinin küs olduğu arkadaşıyla barışmaması (TI, 6), limona alerjisi olan birinin taciz edilmesi (FBII, 1), bahçede çimlere basmak (FBI, 28), aşı yapılacak diye okuldan kaçmak (S, 25) şiddet sebebi olmuştur. Okuldan kaçmak (SI, 19), bayrak töreninden kaçmak, (BI, 6), sabah törenlerinde yerinde durmamak $(\mathrm{M}, 7)$ ya da bu sırada sesli gülmek (BI, 1) de cezalandırılmıştır. $\mathrm{Bu}$ cezalar herkesin içinde verildiği için etkisi daha da kalıcı ve derin olmuştur.

YİBO'da kalan öğrencilerden bazıları dershanelerde belirli saatten sonra konuşmasından (FBI, 10), bazıları yemekhaneden ekmek aldığı için (SII, 28) ya dayak yemişler ya da tehdit edilmişlerdir. YİBO’da kalan bir öğrenci hem okulda hem de burada her gün şiddet gördügünü söyleyerek, "Şiddetin eksik olduğu bir günüm olmazdı" (TI, 25) demektedir.

\section{Okulda şiddetin uygulama biçimleri}

Türk eğitim sistemindeki şiddet nedenlerine bakıldığında oldukça yüksek miktarda çeşitliliğin olduğu görülmektedir. Aynı zamanda sayısal bakımdan da bir artma söz konusudur (Sümer ve Ayrın, 1999, s. 336). Okullarda şiddet uygulama biçimlerinde de büyük bir çeşitlilik olduğu gibi (Altun ve Baker, 2010, s. 8), çocukların biri birlerine de giderek acımasız davrandığ belirtilmektedir (Erşen, 2008, s. 133).

Okulda fiziksel şiddet en başta yer almaktadır. Sonra, sözlü hakaret ve aşağılama ifadeleri gelmektedir. Burada asıl dikkati çeken husus, çeşitli nedenlerle cezalandırılan öğrencilerin gördükleri şiddet biçimlerinden hiç birinin yönetmeliklerde belirtilen disiplin kurallarılya ilgili olmamasıdır.

Okulda fiziksel şiddet uygulama biçimlerinin başında; tokat vurmak, sıra dayağı atmak ve tekme tokat vurmak, cetvel ya da başka bir cisimle her hangi bir tarafına vurmak, kulağını, saçını, kolunu çekmek, tek ayak üstü sınıfın önünde bekletmek, kafa atmak en sık görülen davranışlardır. Bu tür şiddete maruz kalanların sayısı 176'dan daha fazladır. Öğrencilerden bazılarının maruz kaldıkları 
fiziksel şiddete yönelik örnekleri şöyledir: "Ellerime ve bacaklarıma sopa ile vurdu" (FBII, 11), "Başıma defter vurdu" (SÖ, 1), "Dizlerimin altına ve topuklarıma sopa vurdu (TII, 3), "Kafa attı" (BI, 15), "Karnıma tekme attı"(BI, 7). "Kolumu ters çevirip bekletti" (SÖ, 4), "Yumrukla kafama vurdu" (SÖ, 2), "Kitap firlattı ve suratım kesildi, dikiş atılmıştı" (BII, 35). "Kafama sopa ile vurdu" (BII, 3), "Flütle başıma vurdu" (SII, 5), "Öğretmen sandalyesini başıma firlattı" (SII, 10), "Dizime tekme attı" (SII, 14), "Sırtıma tekme attı" (SII, 24), "Öğretmen bana boks yaptı" (SII, 26), "Diğer bir öğrenci ile kafalarımızı tokuşturdu” (SI, 13). "Bacaklarıma tekme ve sopa attı" (FBI, 8), "Başıma anahtarla vurdu" (FBII, 12), "Başıma yumruk vurdu" (BI, 4), "Saçımın arkasından tutarak havaya kaldırdı" (FBI, 16). "Kulak memesinden sıkarak avuç içiyle alnıma vurdu” (FBII, 26), "Ezberleyemediğim kıta sayısı kadar elime sopa vurdu, sınıf başkanı olduğum için bana iki kat vurdu” (FBII, 6).

Tablo 6 verilerine göre, sözel şiddet ikinci sırayı almıştır. Bu tür şiddette, öğrenciyi aşağılama, azarlama, kötü sözler söyleme, hakaret etme hatta küfür etme davranışları bile görülmektedir. Birkaç örnek vermek gerekirse, bir öğrenci kendisine topluluk önünde "ahlaksız, terbiyesiz" diye bağırılmasından hayli etkilenmiştir (FBI, 13). Öğretmenin bir öğrenciye "sen hiçbir şey bilmiyorsun" (FBII, 5) ya da "artık sana güvenmiyorum" (BII, 4) demesi öğrenciyi çok etkilemektedir ve bundan dolayı utanç duymaktadır. Bir başka örnekte ise, anaokulu öğrencisi, okul hizmetlisinin bağırmasından korkup (TI, 8) o günden sonra okula gitmek istememiştir. Bütün bunlar sözel şiddetin çok ve etkili olduğunu göstermektedir. Sözlü şiddetin öğrencileri çok etkilemesinde, bütün okul öğrencilerinin içinde gerçekleşmesi, tören, yürüyüş vb. sıralarda gerçekleşmesi önemli rol oynamaktadır. Anlatıların çoğu toplu tören anlarından seçilmiştir. Öğrenciler en az fiziksel şiddet kadar bu türden de etkilendiklerini ve üzerlerinde kalıcı etkiler kaldığını ifade etmişlerdir.

Tablo 6

En Çok Anlatılan Şiddet Uygulama Biçimleri

\begin{tabular}{|l|c|l|l|}
\hline Görülen şiddet biçimleri & f & Görülen şiddet biçimleri & f \\
\hline Tokat atmak & 71 & Kulağını çekip havaya kaldırmak & 4 \\
\hline Sıra dayağı atmak & 47 & Sopa ile eline vurmak & 4 \\
\hline Sözlü hakaret etmek & 35 & Vücut özellikleri ile alay etmek & 3 \\
\hline Tekme tokat dövmek & 26 & Sinıftan kovmak & 3 \\
\hline Cetvelle başına, dizine ve bileğine vurmak & 13 & Yüzüne kitap, defter vurmak & 3 \\
\hline Cetvelle ellerine vurmak & 12 & Alay etmek & 3 \\
\hline Kulağını çekmek & 10 & Tören geçişinde teşhir etmek & 2 \\
\hline Bir başka öğrenciye dövdürmek & 8 & Saçını çekmek, tutup çevirmek & 2 \\
\hline Ayrımcılık yapmak & 6 & Bahçede temizlik yaptırmak, & 2 \\
\hline Saçından tutup başını tahtaya vurmak & 6 & Azarlamak, kötü söz söylemek & 2 \\
\hline Tek ayak üstü bekletmek & 5 & Öğretmenin küfür etmesi & 2 \\
\hline Düşük not vermek, notla tehdit etmek & 5 & Çöp toplatmak & 2 \\
\hline
\end{tabular}


Fiziksel ve sözel şiddetin hemen ardından en çok görülen ve önemli etkiler bırakan şiddet türü psikolojik olanlardır. Bu türde de ilginç uygulamalar görülmüştür. İlköğretimde bir öğrenci yaramazlık yaptığı için öğretmeni tarafından ders alsın diye çöp kovasına oturtulmuş, bir diğer öğrenci de sınıftaki askılığa ceketinden asılmıştır (TII, 3). Ortaokulda gürültü yaptığı için bir öğrenci eşek gibi bağırmaya zorlanmıştır (BI, 5). Yine öğretmen dalga geçmek için kilolu bir kız öğrenciye, "Sen de patatesin özelliklerini ve ne işe yaradığını anlat" (BI, 37) diyerek dalga geçmiştir. Diğer bir öğrenci "Yüksek sesle konuştum diye etmediği hakaret kalmadı, ne kilolarım ne çirkinliğim” (TI, 12) diyerek psikolojik şiddet gördüğünü anlatmıştır.

Okullarda görülen şiddet türlerinden biri de cinsel şiddet ve tacizdir. Araştırmada 7 öğrenci cinsel şiddete maruz kaldığını anlatmıştır. Şiddete uğrayanların hepsi kızdır ve olaylar ilkokul ve ortaokulda geçmiştir. Bir başka şiddet türü olarak öğretmenlerin ayrımcılık yapması, öğrencileri farklı özelliklerine göre sınıflandırması anlatılmıştır. Bu özellikler fakir-zengin (BII, 16), köylüşehirli (SI, 10) ya da çalışkan-tembel ayrımı şeklinde olmuştur. Bir öğrenci ödev yapmadığında ya da soruyu bilmediğinde tembeller sırası olarak ayrılanlar arasına gönderilmiş ya da tembel olarak nitelenen birinin yanına oturtulmuştur. Böylece büyük bir itibar kaybına uğratılmıștır (BII, 38; FBII, 5). Üstelik o sırada oturanların ne öğretmen ne de diğer öğrenciler önünde hiçbir değeri de olmamaktadır. Öğrencinin yerinin değiștirilmesi de onun üzerinde hayli etkili olmaktadır (BI, 39). Bir öğrenci öğretmenin yüz ifadesiyle bile ayrım yaptığını ve bundan çok üzüldüklerini belirtmektedir (FBII, 19).

Fiziksel ve psikolojik şiddet türlerinden biri de, geç gelen öğrenciyi soğuk havada bekletmek (TI, 13), gürültü yaptığı için ayağına topuklu ayakkabıyla basmak (SII, 5), ödev yapmadığı için, ağzına defter sokmaya çalışmak (SII, 13) şeklinde gerçekleşmiştir. Saçını uzattığı için, farklı yerlerinden kötü biçimde kesmek (FBI, 31) bir başka sınıfın önüne ya da öğretmenler odasına götürülerek orada dövmek (SII, 24) de fiziksel ve psikolojik şiddetin birlikte uygulandığı türlerdendir.

En çok görülen şiddet türlerinden biri de, psikolojik, fiziksel ve duygusal türlerin iç içe geçtiği uygulamalardır. Bunların başında öğrencilerin birbirlerine, büyügün küçüğe, bilemeyenin, bilene, ödev yapmayanın yapana, erkeğin kıza, tembelin çalışkana dövdürtülmesidir. Öğrenciler bu tür şiddeti kesinlikle unutmadıkları gibi, hem öğretmene hem de kendisine şiddet uygulayana çok olumsuz duygular beslemektedir. Bir öğrenci, "Öğretmen bizi gözde öğrencisine dövdürtürdü" (BI, 2) ifadesi, iki taraflı bir duygusal olumsuzluğa işaret etmektedir ya da öğretmenin öğrencileri arasında belirgin bir ayrım yaptığı söylenebilir. Öğretmen "Bizi küçük çocuklara dövdürtürdü" (BI, 16) ifadesi de aynı durumu anlatmaktadır. Bir öğretmenin soruyu bilemeyen öğrencisine "tokat attıktan sonra yüzüne tükürmesi” (SÖ, 19) ise öğrencisini fiziksel, psikolojik ve duygusal bakımdan ezdiğini göstermektedir. Yine öğrencilerin affedemedikleri ve hâlâ etkisinden kurtulamadıkları duygusal şiddet türlerinden biri öğretmenin yüz ifadesiyle sevmediğini göstermesidir (FBII,19).

Bazı öğretmenlerin verdiği ceza ve uyguladıkları şiddet ise simgesel/sembolik-psikolojik şiddetin özgün örnekleridir. Örneğin bir öğretmen ödev yapmadı diye ayakkabısının altını 
öğrencinin kafasına sürtmüştür (BI, 14). Bir diğeri, öğrenciye başında sandalye taşıtmıştır (TI, 5). Bir başkası yaramazlık yapan öğrencisini kravatından kalorifer borusuna bağlamıştır (BI, 5). Lisede bir öğretmen, soruyu bilemeyenleri "Size önlük giydirip diğer sınıfları gezdireceğim" diyerek tehdit etmiştir (SÖ, 4). Bunu anlatan kız öğrenci, "Bunu duyunca yerin dibine girmiştim, korkudan tir tir titremiştim” diyerek, bu tehdidin üzerinde derin iz bıraktığını anlatmıştır.

Öğrencilerden bazıları, öğretmen ya da idare tarafından bazı kitapları almaya zorlanmışlardır. Hatta bazı ögrenciler "Param yoktu, olsaydı zaten almak isterdim, ama buna rağmen ben kitap almadım diye notumu düşürdü” (FBII, 14) diyerek şiddet uygulandığını anlatmıştır. Ekonomik şiddet olarak okulda en çok karşılaşılan türlerden biri de, kırılan camların ya da diğer araçların öğrencilere ödettirilmesi olmuştur (TI, 3, 11). Ekonomik şiddetin duygusal ve psikolojik şiddet ile harmanlandığı bir tür de, bazı özel günlerde öğrencilerin hediye almaya zorlanması olmuştur (BI, 35). Öğretmenler gününde hediye almak için öğrenciler strese girdiklerini, paraları olmadığ için büyük mahcubiyet yaşadıklarını ifade etmişlerdir.

\section{Şiddet malzemeleri}

Şiddet olayı anlatılarında pek çok öğrenci şiddet gördüğü sırasında hangi araçların kullanıldığına dair de bilgiler vermiştir. Bu konuda en çok tekrar edilen şiddet aracı daha çok matematik ve fen bilgisi derslerinde kullanılan araçlardır. Bunların başında metalden yapılmış laboratuvar ve ölçü aletleri, metre, cetvel ve sopa gelmektedir. Bunların dışında çeşitli temizlik araçları, fırça, firça sapı, maşrapa, telli sopa, anahtar ve anahtarlık, çubuk, tahta parçası, tahta kaşık, flüt, öğretmen sandalyesi sıkça zikredilmektedir. Makas, ayakkabı, vazo, önlük, kravat, top, kalem, kitap, defter, kara tahta, kalorifer borusu, tebeşir, kâğıt parçaları, bozuk para, çöp kovası ve tükürük gibi araçlar da şiddet uygularken kullanılmıştır.

\section{Şiddete tepkiler}

Şiddet anında daima karşı koyma ve tepki verme söz konusudur. Ancak bu karşı koyuş farklı biçimlerdedir. En şiddetlisi fiziksel karşı atağa geçmek şeklinde olurken, en hafifi de kötü düşünceler beslemektir. Her ne kadar hırs, tamah ve şiddet arttıkça sorunların çözüleceği beklense de şiddet ile sorunlara çözüm üretilememektedir. Çözüm bir yana, yeni problemlerin ortaya çıkışı kaçınılmazdır (Erten ve Ardalı, 1996, s. 159).

Belli bir kategoriye dahil edilemeyen şu ifadelerin tamamı okul, öğretmen ve öğrenci arasındaki sağllksız iletişimi renkli bir şekilde dile getirmektedir: Bir öğrenci yediği tokattan sonra "Hâlâ o tokadın sıcaklığını hissediyorum" (SÖ, 16) derken, bazıları "Beni dövdükçe daha da inatlaşıyordum" (TI, 5) ya da "Hocaya inat favorileri hep sıfır kestirdim" (BII, 10) diyerek kendini ifade etmektedir.

Ödev yapmadığ 1 için tokat yiyen bir öğrenci artık ödev yapmaktan "Nefret eder hale geldiğgini" (TI, 15) ifade ederken bir diğeri, "Bir daha okula gitmeme kararı aldım" (M, 3) demekte, bir başkası şiddet sonrası utancından "Deve kuşu gibi kafasını kuma gömmek istediğini” (BI, 22) söylemektedir. Çocuk yaşta görülen şiddetin hâlâ hissedildiğini belirten cümleler de hayli fazladır. Özellikle olumsuz düşünceler ve düşler başta gelmektedir. Bir öğrenci "Müdürle bir 
daha karşılaşmak istemediğini" (SII, 11) söylerken, diğer birkaçı da şöyle diyor: "Bu yaşımda bile matematikle cebelleşiyorum" (SII, 27), "Kendimi ezik hissetmeye başladım” (SI, 1), "Rezil oldum, o yaşta ölmek istedim” (BII, 6). Aradan geçen onca yıla karşın "Müdüre kin besliyorum” (BII, 33), "Öğretmeni şimdi bile görsem haşat edeceğim” (SI, 21) diyenler vardır. Görülen şiddetten sonra sadece bir öğrenci "başıma gelenlerden ibret aldım ve bundan sonra hiç okula geç kalmadım" (BII, 9) demiştir.

Şiddet gören öğrenciler, olay anlatıları sonrasında çoğunlukla hak etmedikleri bir davranışla karşılaştıklarını belirtmişler ve bunu asla kabul etmemektedirler. Sadece iki öğrenci "Bu dayağı hak etmiştim, bu ceza benim için uygundu" demiştir. Büyük çoğunluk öğretmenin ya da müdürün kendisini yanlış anladığını ve haksız yere dayak yediğini belirtmiştir. Belki de en çok hatırlananın bu tür hadiseler olduğu için bir yoğunlaşma söz konusudur.

Öğrencilerden biri, "Hiçbir suçum olmadığı halde beni dövdü, şimdi ömür boyu unutamıyorum" (FBII, 10) derken, diğeri "Beni yanlış anladı, konuşan ben olmadığım halde vurdu" (FBII, 4), (SII, 23) demektedir. Benzer şekilde, "Suçu benim üzerime attılar, müdür hiç sormadan dövdü” (SÖ, 6), "İsim benzerliği yüzünden disipline gittim” (SÖ, 22), "Bir arkadaş para çalmadığı halde dayak yedi ve sonra çalmadığı anlaşıldı" (TII, 8), "Yok yere ceza yedim" (TII, 10), "Çöpü ben atmadığım halde beni attı zannederek dövdü” (TII, 18), "Sinavda asla başkasına bakmadığım halde hoca bana iftira attı" (BII, 2), "Öğrenciler sıra olmuştu, ben duymadım, buna rağmen nöbetçi hoca beni dövdü" (BII, 39), "Haksız yere öğretmen beni arabasını çizmekle suçladı” (SI, 4) vb. ifadeler anlatılarda sıklıkla geçmiştir.

Okul ortamında görülen şiddete karşı ilk ve orta öğretimde daha çok duygusal bir karşlık verilmiştir. Karşı gelme, itiraz, şikâyet söz konusu değilken, ilerleyen senelerde hem karşı gelme hem de şikâyet ve hakkını arama davranışları ortaya çıkmaktadır. Bazı öğrencilerin gördükleri şiddeti, legal olarak bir üst merciye şikâyet ettikleri görülmüsstür. Şiddete direnmenin daha ağır şiddet getirdiğini ve daha büyük zarar gördüklerini belirtmişlerdir. Bir üst mercie başvurmanın da anlamsız olduğunu dile getirenler vardır. Zira onlara göre, idare/müdür öğretmenden taraftır ve öğrenciye inanmamaktadır (SI, 26), (TI, 13).

Her ne kadar üst merciye şikâyetin sonuçsuz kaldığı ve öğretmene yönelik bir korumanın varlığı söylense de, şikâyet edenler çoğunlukla istedikleri neticeyi almışlardır. Şiddet karşısında üst merciye gitmeyi birçoğu düşünmüş ancak çok azı gitmiştir. 300 örnek arasında sadece bir kişi Milli Eğitim Müdürüne şikâyete gitmiş, iki kişi okul müdürüne şikâyet etmiş, dört-beş kişi de ailesine durumu bildirmiştir. Sadece okul müdürüne yapılan iki şikâyet sonuçsuz kalmıştır. Diğer şikâyetler içi gereği yapılmıştır.

Bir şiddet olayında eğer öğretmen hatalı ise, bazen idarenin zorlaması ile (BI, 32) bazen kendi isteğiyle (TI, 12; TI, 14), bazen de ailenin (BI, 7) ve sosyal çevrenin baskısılla öğrenciden özür dilemiştir. Şiddet gören bir öğrenci babasına şikâyet etmiş ve ertesi gün okula gelen baba, hocanın üstüne yürüyerek, dövmek istemiştir. Okul müdürü araya girmiş ve öğretmen yaptığından özür dilemiştir (BI, 7). Çivili tahta ile dayak yiyen çocuğun anne-babası ertesi gün okula gelmiş, okul müdürü özür dilemiştir (BI, 8). Benzer örnekler (BI, 22; SI, 15)'in anlatılarında da tekrar edilmiştir. 
Bundan sonraki anlatılar ise oldukça çarpıcıdır. Bir öğrenci sevmediği ve kendisini döven öğretmeni öldürmek için okula satır getirmiştir. Öğretmen kendisine vurmaya kalkınca satırı çıarıp öğretmenin üstüne yürümüştür. Öğrenciler ve diğer öğretmenler koşup satırı güç bela elinden almışlar ve sonrasında öğrenci okuldan atılmıştır (TI, 17). Bir başka öğrenci de şiddet görünce cebinden bıçak çıkarmış ve öğretmenin üstüne yürümüştür (SII, 3).

Başka bir olayda, sınıfta şiddet uygulayan öğretmen, sınıf çetesi tarafından okul kapısında herkesin içinde dövülmüştür (FBI, 2). Bir başka olayda öğrenciler toplanıp öğretmen okul bahçesinde dövülmüş (TI, 13) ve bıçaklanmıştır (FBI, 3). Bir diğerinde, okul müdürü dışarıda öğrenciler tarafından dövülmüştür (TI, 5). Okuldan kaçan bir öğrenciyi sorgulayan müdür yardımcısına öğrenci alaylı bir dille "Devamsızlık hakkımı kullandım demiştir”. Buna çok sinirlenen idareci öğrenciye bir kafa atmış ve yere yatırıp yumruklamıştır. Öğrenci olayı babasına bildirmiş ve baba okula gelip müdür yardımcısını dövmüştür (BI, 15).

Şiddete tepkinin en hazin hikâyelerinden biri ise şöyledir: Lise 1. Sinıfta Fizik öğretmeni ödevini yapmayan çocuğa bir tokat atmıştır. Çocuk da kalkıp karşılık vermiştir. Öğrenci yetkin biri olduğu için, öğretmeni sınıfta kovalamaya başlamış ve koridorda kavga devam etmiştir. Diğer sınıflardan öğretmenler çıkmış ve öğrenciyi dövmüşler. Ardından öğrenci disiplin kuruluna verilmiş ve aynı gün okuldan atılmıştır. Öğrenci okul çıkışında öğretmene bıçakla saldırmış ve iki defa öğretmenin karnına bıçağı saplamıştır. Hastaneye zor yetiştirilen öğretmen son anda kurtarılmış, öğrenci ise üç yıl hapse mahkûm edilmiştir (SII, 32).

\section{Tartışma}

Şiddet çoğu kez bir egemenlik ve hükümranlık isteği neticesinde, keyfî ve zorlamayla ortaya çıkar. Bir olgu olarak şiddet hayatın her aşamasında ve farklı biçimlerde sürekli karşılaşılan bir durumdur. Özellikle eğitim ortamları ve şiddet ise son zamanlarda daha çok ilgi çekici ve araştırma konusu haline gelmektedir. Diğer pek çok ülkede olduğu gibi, Türk eğitim sisteminde de şiddet olaylarına, nedenlerine vb. konularda tutulmuş, kapsamlı ve güvenilir istatistikler bulunmamaktadır. Münferit çalı̧malardan pek çoğu da anket ya da teorik literatür tarama yöntemiyle yapıldığından sağlıklı bilgi ortaya koyamamaktadır.

$\mathrm{Bu}$ araştırma metot bakımından bu güne kadar yapılan bütün benzerlerinden ayrılmaktadır. $\mathrm{Bu}$ metotla, öğrencilere başlarından geçen bir şiddet olayını hikâye etmeleri istenmiştir. $\mathrm{Bu}$ süreçte tamamen gönüllülük esasına dayalı hareket edilmiştir. Fırat Üniversitesi Eğitim Fakültesi dördüncü sınıf öğrencilerinden 400 kişiye istek iletilmiş ve 300 'ü tecrübe ettiği ya da şahit olduğu bir ya da birkaç şiddet olayını yazılı olarak anlatmıştır. Bu yöntemle, anketle bilgi sağlamaya dayalı yapılan pek çok araştırmanın aksine, şiddet olgusu sayısallaştırılmadan, tasvir ve analiz edilmeye çalışılmıştır. Bu durum araştırmanın en önemli ve orijinal boyutunu ortaya koymaktadır. $\mathrm{Bu}$ sebeple araştırmanın teorik literatür boyutuna geniş yer ayrılmamıştır. Metodun oldukça özgün ve sağlıklı veriler ürettiğine inanılmaktadır.

Şiddet sebepleri ve uygulama biçimlerinden pek çoğu bizatihi tecrübe edilmiştir. Bu yönüyle 
anlatılanlar güvenlidir. Araştırma hem tarihsel ve klasik hem de son derece güncel bir nitelik taşımaktadır. Elde edilen veriler ve şiddetin tarafları hâlâ yaşamaktadır ve çok büyük bir kesimi henüz eğitim ortamlarında hayatlarını devam ettirmektedir. Dolayısıyla araştırma sonuçları, eğitim ilgililerinin önlem alması, eğitim politikası belirlemesi için önemli veriler ortaya koymaktadır.

Anlatıların sayısal verilerine bakıldığında eğitim ortamlarında şiddet ilkokuldan üniversiteye her aşamada görülmektedir. Şiddet eğitim ortamının çok farklı bölgelerinde uygulanmaktadır. Ancak çok büyük bir kesimi sınıfta gerçekleşmektedir. İlköğretimde sayı bakımından daha çok ve öğretmenden öğrenciye yöneliktir. Bu dönemdeki şiddetin bireyler üzerinde fiziksel, psikolojik, ahlâki, duygusal ve sosyal bakımlardan derin izleri kalmaktadır. Öğrenciler uğradıkları şiddet dolayısıyla eğitim ortamı ve ilgililerine yönelik derin bir olumsuzluk duygusu ile yüklenmektedirler.

Ortaöğretimde ise şiddetin fiziksel etki boyutu artmaktadır. Sayı bakımından yine yüksek bir seviye söz konusudur. Şiddeti uygulayanlar ise eğitim ortamında bulunan hemen herkestir. Nerede ise bütün öğretmenler şiddet gösterebilmektedir. Kadın ve erkek öğretmenlerin şiddet uygulama sayı ve biçimlerinde de çok fark görülmemektedir. Ancak burada asıl mesele ve şiddet görme nedeni, eğitim sistemindeki statik yapı ve değişime, farklıllğa gösterilen dirençtir. Bunun yanında bir başka neden, eğitim ortamlarındaki davranışların biçimlenmesi ve dondurulmasıdır. Bu hayatı dondurmak anlamına gelmektedir. Bir zaman suç olan bir davranış çok kısa bir süre sonra farklı algılanabilmektedir. Bu da öğretmene şiddet uygulama imkânı tanırken, öğrencide travmaya sebep olmaktadır. Zihniyet değişiminin, değişim ruhunun dikkate alınmaması şiddetin temel bürokratik nedenidir.

Okul ya da sınıf ortamında disiplin yönetmeliklerinde bulunan suç tanımlarından pek çoğu işlenmemesine karşın, öğrenciler şiddet görmüşlerdir. Okula geç gelmek, farklı renkte atkı kullanmak, gülmek, arkaya bakmak vb. hiçbir yerde suç olarak tanımlanmazken pek çok öğrenci sırf böylesi basit sebeplerle şiddet görmüştür. Üstelik disiplin yönetmelikleri öğretmene ceza verme yetkisi tanımamaktadır. Cezayı gerektiren suç işlenmişse, bunun tedricen ve resmî olarak, disiplin kurulu tarafından uygulanması esastır. Ama araştırmadan da görüldüğü üzere şiddetin \%90’̊̈ öğretmen tarafından uygulanmıştır.

Öğretmenlerin öğrenciler tarafından dövülmesi, tehlikeli saldırılara hedef olması, aileler tarafından tehdit edilmesi, hakaret edilmesi ve cezalandırılması azımsanmayacak boyuttadır. Öğrenci şikâyetlerine ve öğretmenlere verilen cezaların tarihlerine ve okul dönemlerine bakıldığında hızla gelişen ve yükselen bir göstergenin olduğu görülmektedir. Bu da öğretmenin itibarından öte güvenliğini bile tehlikeye atan bir gelişmedir. 


\section{Kaynaklar}

Akyol, T. (1991). Politikada şiddet, İstanbul: Mesafe Yayınları.

Altun, S. \& Baker, Ö. (2010). Okuldaki şiddetin etkileri, Çağdaş Eğitim Dergisi, 35(380), 5-11.

Arendt, H. (2003). Şiddet üzerine, (Çev.: Bülent Peker), İstanbul: İletişim Yayınları.

Bailey, K. (1987). Method of social research, New York, London: Collier, McMillian Publication.

Bakır, K. “Anarşizm, Bilim ve Şiddet: Mihail Bakunin”. (2008). Doğu Batı, s.43.

Debarbieux, É. (2009). Okulda şiddet, küresel bir tehdit, (Çev.: İsmail Yerguz), İstanbul: İletişim Yayınları.

Erşen, Ö. (2008). Psikanalitik bir deneme şiddet: öteki’nin yıkımı, Doğu Batı, 43.

Erten, Y. (1996). Cahit Ardalı, "saldırganlık, şiddet ve terörün psikososyal yapıları", Cogito, 6-7.

Freire, P. (2006). Ezilenlerin pedagojisi, (Çev.: Dilek Hattatoğlu, Erol Özbek), Ankara: Ayrıntı Yayınları.

Gerler, E. J. (2004). Handbook on school violence, New York: The Haworth Press.

Gottfredson C., (2001). School and delinquency, Cambridge: University Press.

Gottfredson, D.C. (1985). Victimisation in schools, New York: Plenum Press.

Gözütok, D. (1993). Okulda dayak: bir araştırma, Ankara: Ofset.

Hatipoğlu, Z. \& Aydın, G. (1999). Incidence of violence in Turkish school: a review, International Journal for the Advancement of Counseling, 21(44), 335-347.

Hobart, M. (1996). Şiddet ve susku: bir eylem siyasasına doğru, (Çev.: Yurdanur Salman), Cogito, 6-7.

Morrison, F. (2000). The school in de violence: definition and facts, Journal of Emotional and Behavioral Disorders, 8(2).

O’Donoghue, J. (1995). Violence in the schools, In L.L. Adler, F. Denmark (eds.), Violence and the prevention of violence, U.S.A. Praeger.

Sümer, Z. \& Aydın. H. G. (1999). Incidence of violence in Turkish schools: A review, International Journal for the Advancement of Counseling, 21.

Ünsal, A. (1996). Genişletilmiş bir şiddet tipolojisi, Cogito, 6-7.

Yves, M. (1986). Şiddet (Çev.: Cem Muhtaroğlu), İstanbul: İletişim Yayınları.

“İlköğretmen Okulları Disiplin Yönetmeliği”. (11.07.1967). Resmi Gazete, S. 12644.

"Lise ve Orta Mektepler Talimatnamesi”. (17.10.1931). Resmi Gazete, S.1701.

“Milli Eğitim Bakanlığına Bağlı Temel Eğitim İle Ortaöğretim Kurumları Disiplin Yönetmeliği”. (21.10.1978). Resmi Gazete, S.16441.

“Ortaokullar ve Ortaöğretim Kurumları Disiplin Yönetmeliği”. (12.10.1975). Resmi Gazete, S.15410.

“Toplumsal Bir Sorun Olarak Şiddet Sempozyumu”. (2006). Sempozyumu Sonuç Bildirgesi, İstanbul. 